\title{
Sexuality in the Bayang Community - Mamfe, South West region of Cameroon
}

\author{
Manfred Egbe \\ (MSc. Medical Anthropology and International Health) \\ Medical Anthropology Research Center (MARC) \\ Universitat Rovira i Virgili \\ manfred.egbe@urv.cat/manfredpeace@gmail.com
}

\begin{abstract}
This paper describes the sociocultural, political, economic and ideological systems that shape sexuality in the Bayang community. It shows that initiation into sexual practices occurs before 18 years of age (i.e. before the age at which a person is legally considered mature in Cameroon); and that sexual practices often occur with one or more partners at a regular and/or on a casual basis. It argues that the phenomenon is not peculiar to the Bayang group or community but common in other communities and contexts as well, and shaped by the political, sociocultural, economic and ideological systems of the society. Therefore, sexuality in the Bayang community is shaped by the early emancipation of the male child; the progressive and increased acceptance of 'Western dating cultures'; peer group influence; imitation and experimentation of observed behaviours; changes in traditional value systems, and parental control and authority; economic hardship; and the presence of particular social amenities in the locality.
\end{abstract}

Keywords: sexuality; sexual practices; transformation; economic hardship; change; partner.

Resumen: Este artículo describe los sistemas socioculturales, políticos, económicos e ideológicos que enmarcan la sexualidad en la comunidad Bayang. Demuestra que la iniciación en las prácticas sexuales se produce antes de los 18 años (es decir, antes de la edad en la que una persona es legalmente considerado madura/adulto en Camerún); y que las prácticas sexuales a menudo ocurren con uno o varios pareja de manera regular u ocasional. Se argumenta que el fenómeno no es exclusivo al grupo Bayang o a la comunidad pero común en otras comunidades y contextos también, $y$ enmarcado por los sistemas politicos, socioculturales, económicos e ideológicos de la sociedad. Por lo tanto, la sexualidad en la comunidad Bayang es enmarcado por la 
emancipación temprana de jóvenes varones; la aceptación progresiva y creciente de "culturas occidentales" acerca de amor; la influencia del grupo de pares; la imitación y experimentación de los comportamientos observados; cambios en los sistemas de valores tradicionales y el control y autoridad parental; las dificultades económicas $y$; la presencia de determinados instalaciones sociales en la localidad.

Palabras claves: sexualidad; prácticas sexuales; transformación; dificultades económicos; cambio; pareja.

\section{Introduction}

Sexuality is not a new topic in anthropology. Ever since the age of enlightenment anthropologists have made basic contributions such as the formation of representations about the 'primitive others' and the construction of images of differences within metropolitan societies (Lyons \& Lyons, 2006). However, the approach adopted has been complex and contradictory (Vance, 1991) while the topic itself can be regarded as ambiguous (Lyons \& Lyons, 2011). From the discourse that contributed to representations about the 'primitive others'; favoured biological determinism (i.e. in the decades following World War II), to a more cultural and non-essentialist and social construction theory; such is the checkered history of the topic in the field of anthropology (Vance, 1991, 2005; Maksinowski 2012; Phillips 2010).

In her article 'A Brief History of the Anthropology of Sexuality, and Theory in the Field of Women's Sex Work', Maksinowski explains that our understanding of 'the sexual' has been conditioned by prevailing discourses on sexuality, which have tried to condition human sexual behaviour to defined parameters of what sex can be, where, when, and with whom; and that contemporary dynamics of power, domination and racialization have been imbued with the discourses of sexuality from Western history, the remnants of which persist and shape sexual relations (Maksinowski, 2012). Sexuality is also presented as being constructed within historical relations of difference, 'embedded in political, ideological, social and economic systems' (La Font, 2003). The multitude of discourses reveal the term to be ambiguous: it is difficult to interpret and represent accurately when local, everyday sexual practices are diluted and distorted by an ethnographer's faithfulness to a particular theory or theoretical matrix (Lyons $\&$ Lyons, 2011). It is a fluid term 
that is continuously being redefined both as a term and as a theory informed by practice (Vance 2005; Maksinowski, 2012).

What then is sexuality? Both as a symbolic and as a reproductive behaviour, human sexuality differs across time and space. However, a broad definition describes it as a biological, psychological and cultural (or sociocultural) experience and phenomenon - a means used by human groups to achieve such sociocultural goals as the creation of kin groups (Bolin \& Whelehan, 2009). Biological definitions of the term focus on the physiology of sexual arousal and coitus, and on the reproductive biology of humans (Jacobs Sue Ellen and Roberts Christine, 1989). Behavioural perspectives focus on the behaviours being displayed, by whom, and with what frequency: that is, on how sexual stimuli and behaviours, and the emotional and affective dimensions of the experience are judged, rationalized, attributed, thought about and perceived (Bolin \& Whelehan, 2009). The sociocultural perspective approaches sex as a culturally constituted and created behaviour, and emphasizes the role of customs in framing human behaviour (Gagnon, 1978). Lyons \& Lyons (2006) have indicated there is no concise universally applicable definition of the term. In this study, I approach sexuality in the Bayang locality of Mamfe from the biological and behavioural perspective.

My interest in the topic of sexuality in the Bayang ${ }^{1}$ community - Mamfe, South West Region of Cameroon was aroused by certain observations, experiences and clichés that Bayangs - and particularly the girls are sexually promiscuous. These clichés suggested sexuality to be culturally constituted and created in the group. Moreover, many studies on sexuality in Cameroon have approached the topic from the context of risk filled with a Victorian moral discourse. Kombo (2000) reported that many young people in Cameroon indulge in unsafe sexual activities, therefore running 'the risk' of contracting sexually transmissible diseases and HIV/AIDS and/or experiencing unwanted pregnancies, abortions and even death. Knowledge of HIV/AIDS and its effects do not influence young Cameroonians' involvement in sexual practices; they indulge in unsafe sexual activities at very young ages and often with

1 The Bayang people are Bantus who hailed from Kanem Borno. The Kanem Borno Empire was around Chad and Nigeria, and Bantu languages are spoken around this same area."Two thirds of Africa's languages belong to the Niger-Congo phylum which stretches from the western tip of the continent at Dakar, east to Mombasa, and south to Cape Town". Most clans were on their fourth to fifth migration before history was recorded, so there is little record before the written history of these people. 
multiple casual and/or regular partners (Abega \& Mebenga, 1994; Calvés \& Meekers, 1997). In this paper I show that the sexuality of the people is shaped by sociocultural, political, economic and ideological systems of the society (i.e. peer group influence, imitation and experimentation; transformations of traditional values and parental control mechanisms; economic hardship and social amenities).

\section{Transformations in the Bayang Community}

Mamfe is the headquarters of the Manyu Division in the South West region of Cameroon. Situated in a tropical area, it is marked by two major seasons: the rainy and the dry. The latter is characterized by heavy downpours, which impedes travelling by road. Therefore, it is often a transit city for many travellers and drivers, who spend nights there waiting for sunny days to resume their journey to their destinations. It is full of inns, motels, restaurants and bars, 'provision stores' and several other 'petit trading' businesses.

As far as the sexuality in the area is concerned, the oral history of the people holds that the young and old respected the norms regarding marriage and sex in the past. ${ }^{2}$ Spells were cast on those who showed disrespect for these norms and they were inflicted with physical and physiological defects, which could only be reversed by offering sacrifices to ancestors to revoke the spell. Therefore, the fear of being the victim of a spell acted as system for regulating (premarital) sexual practices in the group. This control system was embodied in traditional societies such as the Ekpe (i.e. a traditional legal and administrative institution) which establishes sanctions for 'deviants', and maintains law and order. This oral history also holds that great harmony and peace reigned in the villages in the area where traditional societies (ekpe) were firmly established and respected.

...in the past a man had sex only with his wife or wives, it was for married people... a young man was not considered mature enough to have sex with a woman if he didn't show proof of moral, material and physical capabilities (i.e. maturity). A man had to hunt and prove he was able to feed a family... In those days, a woman was not given into marriage until she was physically and morally strong, able to work on the farm and cook for her husband...

2 References to the past here refer to the 1940 s to the 1960 s and the 1970 s to the 1980 s depending on the informants who were interviewed. 
The elders of the land and the traditional institutions of the time, like the ekpe today, set norms about sex and marriage and people respected those norms... married people with kids did not 'make love' when their kids were around, their love lives were hidden from their children. Everything was done in hiding and in secret. ${ }^{3}$

It is said in the area that the influx of 'modernity', population and economic growth made major changes to the traditional customs and practices about marriage and sex. With modernity came infrastructural development (i.e. the construction of major routes connecting the area to other cities in the country and neighbouring Nigeria). These routes were used by new settlers, many of whom settled in the area for commercial purposes. Missionaries ${ }^{4}$ (mostly of the Catholic Church) are said to have established institutions that were antagonistic to traditional customs and practices. Many natives were converted to the Whiteman's tradition (Christianity) and took a stand against traditional beliefs and practices, which they condemned as mundane and sinful. Although the doctrines of the 'new institutions' (i.e. the church) are opposed to sex before marriage, these institutions were blamed for not punishing its followers who engaged in sexual relations before marriage. The elderly in the area I interviewed pointed out that the doctrine of confession and forgiveness of sins was a 'passport' for indulging in such practices. After all, any offence they may have committed would be forgiven in confession.

It is also said that development in the area was accompanied by population growth without any corresponding growth in the economy. This situation is believed to have been problematical for many families unable to feed the 'many mouth' they had. It is reported that many young people emigrated to the cities in search of better living conditions ('greener pastures'); some left in an attempt to further their education. This massive emigration of young people meant a considerable loss in labour force for agricultural activities (subsistence farming) and consequently a reduction in the resources generated by these activities. Coupled with the crisis of the 1980s (rising prices, loss of government revenue

3 Extract from an interview with an elderly person in the area on the historical perspectives of marriage and sex in the Bayang group. He was 87 years old and an elder in the chiefs' council.

4 Missionaries were not 'newcomers' or settlers per se. They had settled in the community during the colonial period, but the construction of new routes linking the community to other cities provided new opportunities for other missionaries - Pentecostals, evangelicals, and protestants - to settle and establish their institutions (ministries) in the community. 
and trade deficits) this would eventually leave many parents in such a weak financial situation that they could not provide for the needs of their families. The weakening of the parents' financial situation and the emigration of young people resulted parents losing control over their children. Young people, who traveled to cities ('to town') like Mamfe, learned from very tender ages how to fend for themselves. They took on major responsibilities at very early ages, which possibly gave them a built-in 'sense' of maturity. Because of the availability of social amenities such as inns, motels, hotels, restaurants, nightclubs and bars, elderly people narrating this oral history believe it is obvious that changes in sexuality would take place, especially as some of these social amenities have a latent function that facilitates sexual practices. They note that young people no longer wait until they are 'mature' to indulge in sexual practices.

\subsection{Initiation into sexual practices today}

In their accounts, the elderly say that young people no longer wait until they are mature to indulge in sexual practices. One of the questions the study therefore sought to answer was 'At what age do young Bayangs indulge in sexual practices?' The study also focused on attempting to understand their nature and frequency (i.e. single or multiple partners, regular or casual basis, etc.). A total of 100 Bayangs (40 males and 60 females) resident in the area, aged between 10 and $70+$ years, were selected to participate in the study. In-depth interviews were used to collect the data. Sex being a personal and private practice, there were some initial worries about how to collect the data and whether the data collected could be considered reliable. I was concerned 'potential informants' would not want to talk about their sexuality. These concerns, however, soon faded as pre-fieldwork and fieldwork got underway - all the young and old people contacted were willing to provide information about their sexual experiences and other questions.

Initiation into sexual practices in the area mostly occurs in the age ranges 10-13 years and 14-17 years (i.e. prepubescent, and pubescent). A total of 35 informants had their first sexual experience when they were between 10 and 13 years old; 50 when they were between 14 and 17 . Another 15 engaged in sexual intercourse for the first time when they were 18 years old or older. Generally a person is considered mature (legally) when (s)he turns 18; at this age (s)he 
benefits from all the rights, privileges, and responsibilities established by the law, such as the right to vote, buy and consume alcohol, have consented sexual relations etc. In terms of this 'legal' perspective of maturity, then, initiation into sexual practices in the locality occurs before 'maturity' (i.e. before the age of 18). A total of 85 informants had indulged in sexual practices before they turned 18 years (see table I in Annex).

Not only do young people engage in sexual practices for the first time before the age of 18 , they do so with more than one partner on a regular and/or casual basis. Of the 100 informants, 62 indulged in sexual practices with more than one partner on a regular and/or casual basis (32 in the age group 10-20; 22 in the age group 21-30; and 8 of the age group 31-40 years). A further 26 informants reported indulging in sexual practices with a single partner on a regular and/or casual basis (11 informants in the age group 10-20; 7 in the age group 21-30; 4 in the age group 31-40; 3 in the age group 41-50; and 1 in the age group $50+$. A further 12 informants reported not having indulged in sexual practices at all, indicating that they did not have partners (see table II in Annex).

Informants were also asked what age they considered ideal for a person (male or female) to indulge in sexual practices. Fieldwork findings showed considerable discrepancies between what was considered the ideal age to indulge in sexual practices and the actual ages at which informants did so. Many informants (67) stated that 18 years or $18+$ was ideal for a first sexual experience. Others stated that 14-17 years old was ideal for indulging in sexual practices; they argued that a person is mentally, physiologically and psychologically apt (mature) for sex in this age range (see table III in Annex). According to this group of informants, initiation into sexual practices is not and should not be an issue of age (i.e. until a person turns 18) but an issue of emotional and physical aptness and willingness of the people concerned. These informants' perspective on 'the ideal age' for indulging in sexual practices raises questions about the issue of 'ideal' itself. How has the ideal' been conceptualized and generally accepted as 'right'? Is 18 really the 'ideal' age for initiation into sexual practices? Does maturity occur in every individual at the age of 18 ? 


\subsection{Explaining initiation into sexual practices in the area}

La Font (2003) explains that sexuality is constructed within historical relations, embedded in political, ideological, social and economic systems. In the Bayang community sociocultural, economic, and political systems (i.e. peer group influence, imitation/experimentation, financial hardship, search for pleasure, rape) shape sexuality and initiation into sexual practices.

\subsubsection{Peer group influence, experimentation and imitation}

It is common practice, especially among young people, to recount their sexual adventures, to friends. They often get together in groups during breaks at college and other places to narrate these adventures. Every detail of the adventure (act) is narrated to its attentive audience, and the narrator is often cheered by his/ her peers and considered 'a hero' (at least for the day). Peers without a story to tell, 'the inexperienced', are usually mocked by the 'experienced', held in low esteem and generally encouraged to go in for these adventures. Those of them who have 'lovers' (boyfriend/girlfriend) but have not known them sexually ('virgins') are usually under continuous pressure from peers to have sex with their 'lovers'; sex, they are told, is proof of love and maturity. Afraid of being rejected or pushed out of the group, many young 'inexperienced' people are lured into sexual practices, so that they can get a story to share with the rest of the group, thereby gaining the respect and acceptance of their peers. Those who have most adventures to share with the group are shown more respect so many young people feel encouraged to indulge in sexual practices with more partners (this is more frequent in male than in female peer groups).

... one of my very good friend repeatedly told me there isn't any gain in being a 'virgin', she told me my breasts and butt would never be the right size and shape if I didn't have sex and warned me of the consequences if I had flat breasts and butt- men wouldn't like me because most men love women with nice butts and breasts ... sometimes when I hang out with my friends and their boyfriends, they would make fun of me, telling me to either close my eyes or ears and not see or listen to what they were saying because it is for the 'big guys'. You are the queen of the week when you lose your virginity because you get everybody's attention when you are talking, you are regarded as a brave and wise person because you did something smart. I also decided to 
be the queen of the week and I lost my virginity when I was 14 years old... my friends were very happy and proud of me... 5

In 32 interviews, peer group influence was identified as the reason for indulging in sexual practices. These 32 informants noted that their friends always told them how pleasurable sex is and what they would gain if they had it. Some female informants reported that most of their 'experienced' peers often showed them gifts from their 'boyfriends' and encouraged them to go in for guys who would give them gifts too (i.e. men known as sugar daddies). Many 'experienced' female peers generally dissuaded the 'inexperienced' girls from having affairs with young guys who could not provide for their needs. It should be noted that many of the so-called sugar daddies are married men with a family; they often have more than one partner because they have 'money'. Sugar daddies in the area are often 'petit business' traders, drivers, soldiers, college teachers and other state-employed workers.

... I had sex for the first time when I was 14 years old, basically because I wanted to do those things I always heard my older brother talking about with his friends; the number of girlfriends he had and what he did with them...I really wanted to be like my older brother, to have many girlfriends and tell stories to other friends like he did... I now have two girlfriends, but I hope to have more by the end of the academic year... ${ }^{6}$

Sexual experiences are also recounted in mixed groups of both older and younger boys/girls and people from different walks of life. The younger people in these mixed groups listen to the group discussions and take part. Because the skills, attitudes, beliefs and values that underlie behaviour as well as behaviour itself are generally learned by observation, imitation, and social learning (Ward and Edelstein 2006; Toroitich-Ruto 1997), the younger people in these groups observe, learn and imitate what they hear or see older people do. This desire to imitate and/or experiment what they see and hear older people do was a great motivation to some younger people.

5 Ma'Agbor, 18-year-old college student at the Government High School, Mamfe.

6 Atem, 16-year-old student from the Government Secondary School Mamfe. 


\subsubsection{Economic hardship}

As Meekers (1993) observed, economic hardship and aspirations of 'material gain' lured young people into sexual practices at an early age with partners of better social and/or economic status. This is the case (especially for girls) in the Bayan locality of Mamfe. Most of the young girls' partners were 'wealthy': that is, they had material wealth like an expensive car, and were able to provide them with their basic needs and some luxuries. The economic crisis of the mid1980s and early 2000s in Cameroon hit many families hard and parents were literally unable to provide for the basic needs of their families. Mostly the very basic needs (food, education, and housing) were priority and could be provided for. Any other needs were not considered priority by parents although they may have been by their children. In this context indulging in sexual practices for 'material gain' (particularly young people from 'very poor' homes) seems an easy way out of their 'plight' (poverty). Generally, many young people are students and unemployed, so the possibility of having a partner (sugar daddy) who can provide for their needs, especially school needs, is one greatly desired by many young people.

Fieldwork reveals the relationship between the ability to provide for needs and wants, and sexual practice. It is more likely that young people will engage in sexual practices with one or more partners if they can provide for their needs and wants. People with stable and permanent jobs (state-employed workers civil servants, petit business traders, drivers and bike riders) indulge in sexual practices with more than one partner on a regular and/or casual basis. Of the 20 petit business traders interviewed, 18 reported having indulged in sexual practices with more than one partner on a regular and/or casual basis. A further 22 informants (drivers and bike riders) also reported having indulged in sexual practices with more than one partner on a regular and/or casual basis (see table IV in the Annex). The partners of these informants (i.e. stateemployed workers, petit business traders, drivers and bike riders) are mainly young college students and, as noted above, most of these relationships are extramarital affairs since most of the men (sugar daddies) are married.

Involvement in sexual practices with 'financially viable' partners is not a route chosen by all young people (girls) in the area as way out of economic hardship. Some embark on 'petit trading' businesses during the summer holidays to 
generate income to cover the basic expenses of the next academic year. They may sell baked/cooked groundnuts, grilled corn (maize) or cooked food. Many of the young people involved in these petit businesses often carry the products on their heads or in two wheel hand trucks around the 'quarters' (i.e. neighbourhoods) of the locality in search of customers. Others are stationed at permanent sites (major roundabouts and popular spots). Many of the young people (girls) involved in this activity are teenagers and adolescents and some of them became victims of sexual harassment and rape:

... I got pregnant when I was 15 years old, I was raped... it was during the summer holidays when I began a little business - selling cooked groundnuts to help raise some funds for 'school return'. One day, I was going through the Llala 'quarter'. A customer stopped me to buy, it was a guy. I think he was about 25 years old. He was sitting on the veranda of an apartment there and there was nobody else around at the time he called me over. I asked him how many groundnuts he wanted and he said 100XAF (i.e. €0.15). I got the groundnuts and I reached out to give them to him, he got hold of my arm, touched my butt and breasts and said we should have sex. When I tried to resist, he forced me into a dark room nearby and raped me... I got so scared I was unable to tell my parents what had happened. I could only tell one of my aunts. She took me to the hospital for a check-up; we were told three weeks later that I was pregnant...

Ebot $^{8}$ is a young Bayang female. She had just turned 17 at the time this interview was conducted. She was in college when the incident occurred and had to dropout of college to take care of her baby. Ebot never went back to college again and there was no sign she ever will. She noted that her major concerns and objectives are to take care of her baby, bring her up and ensure her wellbeing. Ebot's baby was 2 years old at the time of the interview; she continued doing the same business and is now established in a permanent site. Her parents help her and her baby when they can. Meanwhile, the 'rapist' was never caught. Ebot's story testifies to the fact that economic hardship in the locality, as in other localities of the country, creates contexts that expose young

7 Ebot - a single parent and school dropout living in Mamfe.

8 All names used here are pseudonyms and not the real names of any of the informants who have contributed to this study. 
people to sexual violence. It creates and recreates 'webs of entanglement' for young people, who end up in sexual practices.

\subsubsection{Changes in traditional values and parental control and authority}

Constant changes in traditional control systems and the authority of the elderly over the young, especially as far as sexual practices are concerned, help promote the initiation of young people into sexual practices at early ages; young people are no longer accountable for their deeds to the old (Meekers and Ghyasuddin, 1999). Many young people (males in particular) were observed to have many privileges and be quite autonomous from parents. Some boys who were still not 18 years old lived in apartments by themselves away from their parents and other siblings (females and 'younger males') though usually in the same property (i.e. 'compound'). These are usually apartments annexed to the main apartment. They are known as the 'boys' quarter', they are hardly ever visited by parents, and they are rarely monitored. Young people living in the 'boys' quarters' hang out late at night with whoever they like and whenever they like; they often go to parties and come back late or lend their apartment to older boys' for their love affairs in exchange for money or gifts. Generally, only males who are 18 or older are allowed to live in the 'boys' quarter' but we found that they were occupied by a great deal of males under 18. Many 'inexperienced' young people had their first sexual encounter in the 'boys' quarters', which serve as 'apprentice sites' for many. Several young people living in the 'boys' quarters' are sexually active and reported having partners.

The fact that males can live in one apartment and parents and other siblings (female and 'younger males') in another is evidence of an obvious gender discrepancy in the area. Daughters are not allowed to live in annexed apartments (even when they are over 18); they belong with their parents, where they can be closely controlled and monitored. This gender discrimination may be the result of the value or esteem associated with the virginity of marriageable girls or the lack of value of girls in society. It should be noted that society is highly patriarchal: the males hold primary power and control and the male child is the father's heir irrespective of whether there are older female siblings. Women without male children are despised by their in-laws and often accused of being witches (they are said to eat their male kids). This differentiation between the 
genders in questions of housing may also reveal that there is no parent-son relation and, therefore, no control over young males. There is little contact between the males who live in 'boys' quarters' and their parents as they often go to the main apartments only for meals, and most families are not in the habit of eating together. Therefore, there is little or no conversation between parents (especially fathers) and these young males). Subjects like sex are often not common in families, parents rarely talk about it with their children and when they do, it is often from a moral and 'be careful' perspective:

Do not have a boyfriend/girlfriend... do not have sex before marriage... because you will contract HIV/AIDS or get pregnant and be thrown out of school...

In the current context of increased 'immorality' and an increasingly 'vulgar media' that is accessible to many in society, moral discourses on the subject stand no chance of dissuading young people from indulging in sexual practices. Moreover, Western cultures about dating have been introduced (mostly by the audio-visual media) and accepted; young people now present their partners (boyfriends/girlfriends) to their parents and there is no objection or disapproval of the 'culture' by the latter. This was not the case in the past (2-4 decades ago). Parents generally found wives for their sons to marry when they were considered ready for matrimonial life. Over time Western cultures became more familiar because of propagation by the mass media (especially the television) so young people began to talk about their relationships, mainly with their mothers. At first fathers were still greatly respected and feared, and children spoke little to them about these issues and did not introduce them to their partners. Now, however, they do talk about their partners and introduce them (sometimes more than one) to their parents. Not only is this new and not objected to by several parents, some parents do not question or advise their children who introduced more than a single partner to them. The acceptance of favours - drinks, money and gifts from the partners introduced - is believed to explain this lack of rejection or questioning attitude. Some parents (mothers in particular) are even reported to have advised their daughters on their choice of partner (or suitor) and to go in for the 'wealthy' rejecting partners believed to be 'poor'. This does not happen in every family but often does in the poorest of them. 
Many younger siblings are sometimes exposed to sexual practices in this 'new context of conformity' in which partners are presented to parents. This is because they often play the role of the middle man (errand boys/girls) between their older siblings and their partners. They deliver love letters, messages, gifts etc. Some of these messages are obscene and as they continue in this role, they tend to imitate and/or have the same experiences. In addition, girls who become pregnant before marriage are no longer 'discriminated' against or 'undervalued' (concerning marriage). Neither are the men responsible for the pregnancy obliged to marry them as they used to be. They are now only required to pay the girl's family some sort of compensation (see Tchupo et al. 1996).

\subsubsection{Social amenities and sexual practices}

There are many social amenities (bars, restaurants, motels, inns, 'petit trading' businesses) in Mamfe. They have a double-faceted role that shapes people's sexuality. These amenities are often the 'birth places' (initiation sites) and practice (consumption) sites for sexual practices in the area. It is where many young people are introduced to sex or have their first sexual experience. Moreover, the employees at these social amenities are usually young people - mostly young teenage or pubescent girls. Many of them come from the villages around Mamfe, are primary school dropouts or uneducated, and have come to the town from the village for the first time. It is worth noting that most of the young teenage and adolescent girls hired to work in the bars, inns, motels or restaurants were mostly attractive and dressed to expose specific parts of their body (belly, thighs, breasts, and back). The managers of these businesses recommend that they dress in this way because they believe it attracts customers, especially male customers.

Many male customers of these businesses did not come to buy only what was sold (drinks, food or lodging); they were also seeking 'the products' the managers were advertising (the body of the young teens and adolescents). Therefore, they flirted with the young bar attendants, the inn and motel receptionists, the cleaning girls and the waitresses. Some of them touched the girls' buttocks, thighs, bellies or breasts while they served at their tables; others made direct sexual advances. Some of the young girls (bar attendants) interviewed reported that they were tired of complaining because they had 
done so on many occasions. Managers did nothing to help the situation and reminded them that the customer came first and that they were there to serve customers and not complain. It is worth nothing that some of these incidents took place in the presence of the managers. Constant pressure and harassment from customers without any support from managers or employers has prompted some of these young girls to succumb to the sexual advances of some customers. A couple of them said that they had had affairs with some customers.

Flirting in these places is not an entirely male affair. Some girls frequent bars and other popular spots, flirting with boys or men so that they will buy them drinks or something to eat. Most young girls love the 'soya' (roast beef) and 'roasted fish' (also known as 'burning fish') usually sold in the bars and popular spots. During the fieldwork, a 16-17-year-old girl was observed in one of the famous bars in Mamfe sitting at the table at the far end of the terrace. A few tables away was a group of about five men drinking and eating 'soya' and when she realised that she was hidden from them by one of the terrace pillars, she changed tables so that she could be closer. No sooner had she settled at her new table than one of the men at the other table invited her to join him and his friends. She did not hesitate, and she was offered a drink and some 'soya'. She also left with the group when they had finished drinking at that bar. Two weeks later I observed the same young girl do exactly the same in another bar. I had a word with her about the study I was conducting and asked if she would like to be one of my informants. She agreed and in the interview I had with her said the following:

...whenever I want a beer, and eat some soya or roasted fish, I put on something sexy, a bit of make-up, and go and sit in one of those bars, you know, where people always hangout .... guy will always spot you and come and talk to you ... he will buy you a drink and some roasted fish or beef... that's what guys do... 9

Besong has been doing this for about sixteen months because she enjoys 'playing' with these men. She pointed out that she does not get emotionally involved with the men but also said that she had had sexual relations with one of them because she really liked him.

9 Besong, school drop-out and resident in Mamfe. 


\section{Conclusions}

In this paper, which assumes that practices can only be understood if they are interpreted by those involved (Kleinman 1987), I have shown that young people have their first sexual experiences before they are 18 (i.e. before they are legally considered mature in Cameroon); and that sexual practices often occur with one or more than one partner on a regular and/or casual basis. More importantly, this phenomenon is not peculiar to the Bayang group or community but common to other communities and contexts and is shaped by the political, sociocultural, economic and ideological systems of the society. As noted by the above analysis, sexuality in the Bayang community of Mamfe is no longer what it used to be. It has undergone several transformations as a result of the early emancipation of the male child, the progressive and increased acceptance of 'Western dating cultures', peer group influence, imitation of observed behaviours and experimentation, changes in traditional value systems and parental control and authority, economic hardship, and the presence of particular social amenities in the area. Also, as Meekers and Ghyasuddin (1999) point out, these transformations are also encouraged by the fact that boys and girls now meet in schools, or grow up in single-parent households where parental control is weak and/or absent. Moreover, initiation ceremonies into maturity are now in the hands of modern religious institutions that have little control over sexual behaviour. Therefore, sexuality is moulded by the 'internal logic and consistency of the total culture... as one sector of culture changes, all other sectors that articulate must undergo adjustment' (Davenport, 1977). 


\section{Annex}

Table I: Age at first sexual intercourse

\begin{tabular}{|c|c|c|c|c|}
\hline Age at first sexual intercourse & $10-13$ & $14-17$ & $18+$ & Total \\
\cline { 2 - 5 } & 35 & 50 & 15 & 100 \\
\hline
\end{tabular}

Source: author's fieldwork

Table II: Age distribution and initiation into sexual practices (number of partners)

\begin{tabular}{|c|c|c|c|c|c|c|c|c|c|c|c|c|}
\hline & \multicolumn{2}{|c|}{$10-20$} & \multicolumn{2}{|c|}{$21-30$} & \multicolumn{2}{|c|}{$31-40$} & \multicolumn{2}{|c|}{$41-50$} & \multicolumn{2}{|c|}{$50+$} & \multicolumn{2}{|c|}{ Total } \\
\hline & M & $\mathrm{F}$ & $M$ & $\mathrm{~F}$ & $M$ & $\mathrm{~F}$ & $\mathrm{M}$ & $F$ & $M$ & $\mathrm{~F}$ & $M$ & $\mathrm{~F}$ \\
\hline Single partner & 1 & 10 & 1 & 6 & 2 & 2 & 2 & 1 & 1 & 0 & 7 & 19 \\
\hline More than one partner & 14 & 18 & 11 & 11 & 8 & 0 & 0 & 0 & 0 & 0 & 34 & 28 \\
\hline None & 1 & 9 & 1 & 1 & 0 & 0 & 0 & 0 & 0 & 0 & 2 & 10 \\
\hline Total & 16 & 37 & 13 & 18 & 10 & 2 & 2 & 1 & 1 & 0 & 43 & 57 \\
\hline Total & & & & & & & & & & & & \\
\hline
\end{tabular}

Source: author's fieldwork

Table III: Ideal age for sexual relations

\begin{tabular}{|c|c|c|c|c|}
\hline \multirow{2}{*}{ Ideal age for sexual relation } & $10-13$ & $14-17$ & $18+$ & Total \\
\cline { 2 - 5 } & 14 & 19 & 67 & 100 \\
\hline
\end{tabular}

Source: author's fieldwork

Table IV: Occupation and sexual practices

\begin{tabular}{|l|c|c|c|c|c|}
\hline & Civil service & Business & Driving/Riding & Student & Total \\
\hline Single regular partner & 18 & 1 & 1 & 8 & 28 \\
\hline More than one partner & 10 & 18 & 20 & 11 & 59 \\
\hline None & 3 & 1 & 0 & 9 & 13 \\
\hline Total & 31 & 20 & 21 & 28 & 100 \\
\hline
\end{tabular}

Source: author's fieldwork 


\section{References cited}

Abega, S.C. et Mebenga, T.L. (1994). "Apprentissage et vécu de la Sexualité chez les jeunes Camerounais de 15 à 30 ans." U.Y.I/OMS. Rapport de Recherche.

Bolin, A., \& Whelehan, P. (2009). Human sexuality: biological, psychological, and cultural perspectives. New York: Routledge.

Calvés, A., \& Meekers, D. (1997)."Gender Differentials in Premarital Sex, Condom Use and Abortion: A Case of Yaounde Cameroon." Working papers no 10. Research Division-Social Marketing and Communications for Health, Washington DC PSI.

Davenport, William H. (1977). "Sex in cross-cultural perspectives." In Frank Ambrose BeAch and Milton Diamond (ed.), Human sexuality in four perspectives (pp. 115-163). Baltimore: The John Hopskins University Press.

Farr, D. (2006). "Endemic poverty". In M. Odekon (ed.) Encyclopedia of world poverty. Sage publications, pp. 309-310. Accessed on July 21, 2014 at: <http://dx.doi.org/10.4135/97814112939607.n209>.

Gagnon, John. H. (1978). "Reconsiderations.” Human Nature, 1(10), 92-96.

Jacobs, Sue Ellen and Roвerts, Christine (1989)."Sex, sexuality, Gender and gender variance." In S. Morgen (ed.), Gender and Anthropology: Critical Reviews for Research and Teaching (pp. 438-462). Washington: American Anthropological Association.

Katchadourian, Herant A. (1979). Human sexuality: a comparitive and developmental perspective. Berkeley: University of California Press.

Kleinman, R.L.; Wanstall-Sauty, M., and Chasey, C. (1987). L'Adolescence et la Sexualité, ses Difficultés et ses Dangers. Un Guide à l'intention du Personnel des Cliniques, des Parents et des Enseignants. London. International Planned Parenthood Federation.

Комво, N. K. N.A. (1995). "Changement du comportement sexuel à risque d'infection par le VIH/SIDA; cas des Provinces du Nord-Ouest et du Sud-ouest Cameroun". IFORD, Cameroon.

La Font, Suzanne (ed.). (2003). Constructing sexualities: readings in sexuality, gender and culture. Upper Saddle River: Prentice Hall. 
Lyons, Andrew. P. and Harriet Lyons (2006). "The new anthropology of sexuality". Anthropologica.

- (eds.) (2011). Sexualities in anthropology: a reader. Sussex, UK: WileyBlackwell.

Meekers, D. (1993). "Sexual Initiation and Premarital Child Bearing in Sub-Saharan Africa." Working papers. Demographic and Health Surveys, (DHS), Columbia. Macro International Inc.

- and Ghyasuddin, A. (1999). "Pregnancy-related school dropouts in Botswana." Population Studies, Vol. 53, No. 2 pp. 195-209. Accessed on June 23, 2014 at <http://www.jstor.org/stable/2584676>.

Phillips, Robert F. (2010). "Sex and sexuality”. In Barnard, Alan; Spencer, Johnathan (ed.), The Routledge Encyclopedia of Social and Cultural Anthropology (second edi. pp. 637-638). New York: Routledge.

Tchupo, J.P.; Kuepie, M.; Dipoko, D.; Аввo, M.; Barnes, J.; Timyan, J, and Meekers, D. (1996). "Projet de recherche opérationnelle sur la santé reproductive des adolescents au Cameroun: données quantitatives de base à Edea et Bafia”. Washington, D.C., Population Services International, Research Division, 74, pp. 13. Accessed on June 20, 2014 at: <http://www. popline.org/node/309439\#sthash.3X1TK1S3.dpuf>.

Toroitich-Ruto, C. (1997). "The Determination of Teenage Sexuality and their Understanding of STD/HIV/AIDS in Kenya." African Population Studies. Vol 12, No 2.

Vance, Carol. S. (1991). "Anthropology rediscovers sexuality: A theoretical comment". Social Science E Medicine, 33(8), 875-884. Doi:10.1016/02779536(91)90259-F.

- (2005). "Anthropology rediscovers sexuality: a theoretical comment". In J. Robertson (ed.), Same-Sex Cultures and Sexualities: An Anthropological Reader (Malden, MA.). Blackwell Publishing.

Ward, Martha and Edelstein, Monica (2006). A World Full of Women. Boston: Pearson A and B. 